\section{Cooper's Hawk Nest}

By DOUG GILROY

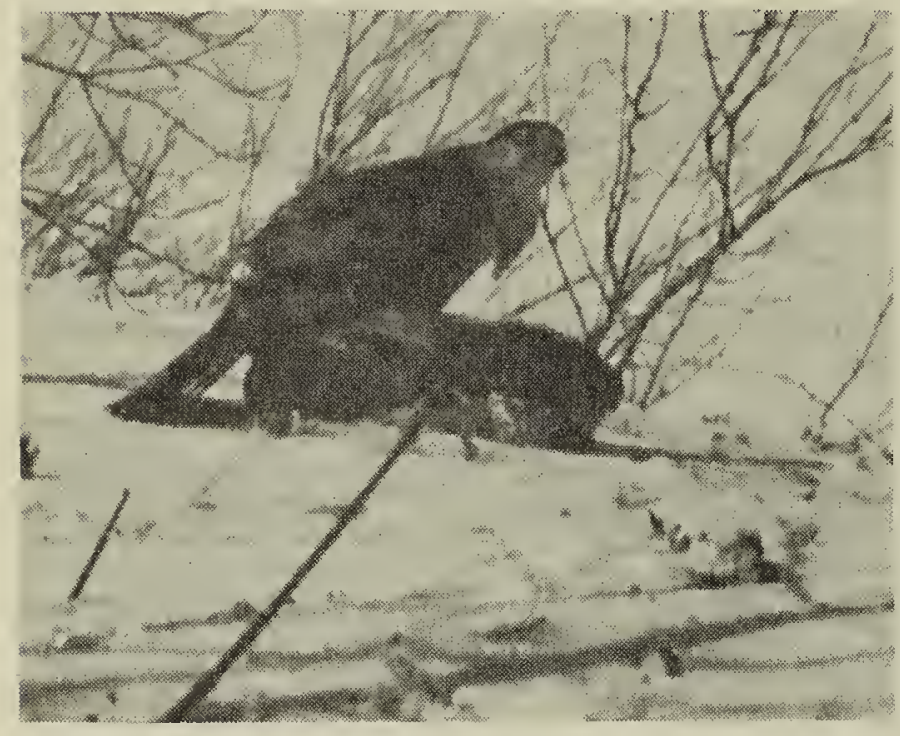

The picture above is of a Cooper's Hawk feeding on a pigeon he has just killed. Although the Cooper's Hawk is considered to be rather rare in the Regina region we see them quite often here on the farm and on two occasions I have stumbled across their nest.

One evening a few years ago I saw a Crow's nest up quite high in an Ash Tree. Just for fun we gave the tree a vigorous shake expecting to see a Crow fly out or at least hear the young. The next thing we knew it was literary raining hawks; six young three quarter grown Cooper's Hawks came hurdling out of the nest to land in the grass and bushes all around us.

The adult suddenly appeared out of the thin air and came whishing past my head uttering short sharp screams in rapid succession. Last summer we again found a nest about a mile from the other one. This was discovered when the adult flew out of the nest and we walked under it and again repeating her shrill call. Climbing up we found two handsome young about a quarter grown and one addled egg.

It was about 9 p.m. and rapidly growing dark so we decided to wait and come back next day for pictures. On our return all we found in the nest was the egg. The young had been spirited away by what and by whom we do not know.

Cooper's Hawks usually lay from three to six eggs, bluish or greenish white in color and are often spotted with pale reddish brown.

\section{Conspicuous Changes in Fauna \\ $1905-1955$}

By J. H. TAYLOR, Regina

Not so many changes have taken place in the fauna of southern Saskatchewan since 1905. However there have been a few.

The buffalo and grizzly bear had already disappeared when the province was formed. Gophers, though, were many times more numerous, as were jack rabbits, coyotes, badgers, red and kit foxes. The red fox is staging quite a comeback, but the kit fox is having a much more difficult time to survive. These little animals were a pest, due to their habit of chewing and spoiling leather, such as harness and saddles. Their disappearance from a neighborhood was welcomed. From a fur standpoint their pelts were useless.

Antelope, although not plentiful, might be seen anywhere on the open prairie. It was not until after the coulees and valleys were somewhat forested that they made their appearance.

As to bird life, the same birds were in evidence then as now. Some species have increased and some have all but disappeared. The robin, who follows civilization, was scarce then. He, like the deer, needed the trees and waited for the settlers to plant windbreaks. The fantail, pinnated grouse, or prairie chicken was the commonest upland game bird. They were the real open prairie dwellers. To all lovers of nature, their flight for existence, as with the whooping crane, is to be regretted.

Hungarian partridge and pheasants were late arrivals, being introduced about the year 1910. Magpies moved in about this time too. Some of our migrants, listed as game birds, might have become extinct had not the Migratory Bird Act been signed and enforced by the United States and Canada. Due to this Act we still enjoy the mourning dove and the marbled godwit.

In this Jubilee Year of 1955, we should take into account the debt of gratitude we owe to the North American conservationists for the heritage they have preserved for us. 